\title{
Qual democracia? contribuições de Jeremy Waldron para a crítica ao protagonismo judicial no neoconstitucionalismo ${ }^{1}$
}

Which democracy? contributions by Jeremy Waldron to the criticism of judicial protagonism in neoconstitutionalism

\author{
Melissa Mendes de Novais ${ }^{2}$ (iD) e Alexia de Melo Miguel $^{3}$ \\ ${ }^{2}$ Universidade Federal de Santa Catarina (UFSC), doutoranda em Direito, email: melissamendes91@gmail.com \\ ${ }^{3}$ Universidade do Vale do Itajaí (UNIVALI), graduanda em Direito, e-mail: alexiamiguel13@gmail.com
}

\section{RESUMO}

A relação entre o Poder Judiciário e a democracia é tema de relevância na contemporaneidade, uma vez que o agigantamento da esfera jurisdicional tende a relegar aos espaços democráticos um papel subsidiário na sociedade. A centralidade do Judiciário, agravada pelo que Oscar Vilhena Vieira chama de "Supremocracia" trata-se de mais uma narrativa que retira o poder de decisão da esfera da soberania popular. Nesse sentido, a atuação do Judiciário, baseada em uma posição neoconstitucionalista ou pós-positivista do Direito, deve ser questionada. As críticas ao neoconstitucionalismo não advêm, todas, de um mesmo modelo teórico, mas o referencial adotado será o de Jeremy Waldron, que prestigia o autogoverno e a perspectiva majoritária da democracia. Logo, deve-se tomar a teoria constitucional hegemônica que consolida o empoderamento do Poder Judiciário via controle de constitucionalidade a partir de seus problemas e limitações, tanto teóricos quanto práticos, tendo em vista a realidade do Poder Judiciário no Brasil. Dessa forma, pretende-se responder aos seguintes questionamentos: de que democracia se fala quando o Judiciário está posto em discussão? Qual reflexo tem a posição neoconstitucionalista ou pós-positivista do Direito adotada pelos tribunais brasileiros? Como a crítica de Jeremy Waldron contribui para se repensar o modelo de funcionamento do Judiciário posto e reforçar as estruturas democráticas? Para tanto, o método de procedimento é o monográfico e as técnicas de pesquisa são a bibliográfica e a documental.

Palavras-chave: Judiciário. Democracia. Neoconstitucionalismo. Controle judicial. Jeremy Waldron.

\begin{abstract}
The relationship between the Judiciary Power and democracy is a relevant topic nowadays, since the increase in the jurisdictional sphere tends to relegate to democratic spaces a subsidiary role in society. The centrality of the Judiciary, aggravated by what Oscar Vilhena Vieira calls "Supremocracy", is another narrative that removes decision-making power from the sphere of popular sovereignty. In this sense, the performance of the Judiciary, based on a neoconstitutionalist or post-positivist position of Law, must be questioned. The criticisms of neoconstitutionalism do not all come from the same theoretical model, but the framework adopted will be that of Jeremy Waldron, who honors self-government and the majority perspective of democracy. Therefore, one must take the hegemonic constitutional theory that consolidates the empowerment of the Judiciary through control of constitutionality from its problems and limitations, both theoretical and practical, in view of the reality of the Judiciary in Brazil. Thus, it is intended to answer the following questions: what democracy is being talked about when the Judiciary is under discussion? What is the reflection of the neoconstitutionalist or post-positivist position of law adopted by Brazilian courts? How does Jeremy Waldron's critique contribute to rethinking the functioning model of the judiciary in place and reinforcing democratic structures? Therefore, the procedure method is monographic and the research techniques are bibliographic and documentary.
\end{abstract}

Keywords: Poder judicial. Democracia. Neoconstitucionalismo. Control judicial. Jeremy Waldron.

\footnotetext{
${ }^{1}$ Artigo realizado por meio do programa de bolsas de pesquisa do artigo 170 da Constituição de Santa Catarina (SC).
}

Ciências Sociais Aplicadas em Revista, v. 20, n. 38, p. 203-237, semestral, janeiro-junho, 2020. 


\section{INTRODUÇÃO}

O tema da relação entre o Judiciário e a democracia demonstra a sua relevância num contexto de agigantamento do Poder Judiciário no Brasil, seja no que concerne aos seus custos, quanto no que diz respeito à visão que a sociedade tem sobre os poderes dos juízes, à judicialização da política, à postura ativa do Judiciário na formulação de políticas públicas e quanto à profusão de teorias que apostam numa liberdade interpretativa e argumentativa que confere ao Judiciário um espaço cada vez mais destacado na arena política brasileira. Mas esse papel que vem sendo ocupado pelo Judiciário não se consolida sem críticas.

As principais questões políticas e morais são definidas pelo Judiciário, especialmente pelo Supremo Tribunal Federal (STF). O problema é que conferir a última palavra sobre o direito e a política a uma instituição composta por ministros não eleitos e que não decidem essas importantes questões à luz de um modelo autenticamente deliberativo, serve para se repensar o modelo de democracia trabalhado pelo neoconstitucionalismo.

Decisão por somatória de votos, alteração do resultado da decisão pela alteração na composição do tribunal, ausência de uma estrutura de precedentes que leve em consideração a coerência argumentativa, personalismo das decisões, etc. são alguns dos problemas que convocam à reflexão se o Judiciário seria mesmo o melhor lugar para definição sobre desacordos morais na sociedade. Outros problemas poderiam ser colocados, mas o mais importante, nesse contexto, é o déficit de representação, legitimidade, responsabilidade, transparência e participação pressupostos no modelo predominante.

Dessa maneira, espera-se compreender e identificar as características da atuação judiciária, a qual é baseada, principalmente, nas teorias pós-positivistas e neoconstitucionalistas do direito. Ademais, pretende-se analisar as relações entre o Judiciário brasileiro ${ }^{2}$ e o tipo de democracia sustentado pela teoria do direito e pela prática do Judiciário, com o fulcro de analisar o argumento sobre a desnecessidade do controle judicial sobre a atividade do legislativo. À vista disso, este estudo estrutura-se em diversos momentos como: a relação entre o Judiciário e a democracia; a democracia frente ao neoconstitucionalismo; a tendência ao pós-positivismo e sua repercussão no ambiente brasileiro; a fragilidade das abordagens neoconstitucionalistas; a propensão à judicialização da política e a crítica de Jeremy Waldron com relação ao controle judicial realizado

\footnotetext{
${ }^{2}$ Salienta-se que, como instância representativa do Poder Judiciário, este artigo irá se pautar, principalmente, na atuação do Supremo Tribunal Federal (STF). Também como medida para viabilizar o estudo, já que o Poder Judiciário brasileiro é uma esfera de grandes dimensões, cuja análise não se esgotaria em um único artigo, decide-se ter o STF como foco de compreensão.
}

Ciências Sociais Aplicadas em Revista, v. 20, n. 38, p. 203-237, semestral, janeiro-junho, 2020. 
sobre a atividade legislativa.

O estudo em questão pretende, neste primeiro momento, apresentar uma visão descritiva da atuação do Judiciário, de sua relação com a democracia e apresentar as possíveis críticas a partir do referencial de Waldron. Desse modo, não há o objetivo de oferecer soluções para o problema posto, mas antes proporcionar um espaço de discussão acerca do papel reivindicado pelo Judiciário brasileiro atualmente e o impacto causado na atividade legislativa.

A fim de atingir os objetivos propostos, adota-se o método dedutivo de abordagem. $\mathrm{O}$ método de procedimento é o monográfico e as técnicas de pesquisa são a bibliográfica e a documental.

\section{O PODER JUDICIÁRIO E A DEMOCRACIA}

É bem conhecida a história de Ulisses e seu episódio com as sereias, bem como a associação dessa passagem da Odisseia com a atividade do poder Constituinte Originário. Essa imagem formulada por Spinoza (SPINOZA, 1994) e depois resgatada por Elster (ELSTER, 1989) e por Holmes (HOLMES, 1988b) é bem difundida no Brasil (BARRETO; OLIVEIRA; STRECK, 2009). A metáfora indica uma perspectiva de Constituição como pré-compromisso e autolimitação, fruto de um momento histórico específico, em que a Constituição aparece como mecanismo de limitação do poder. No caso da concepção de Holmes, essa limitação se refere à democracia, de forma que a soberania popular deve ser contida para se proteger os direitos fundamentais.

Segundo Pietro Costa (COSTA, 2010, p. 93), é "historicamente recorrente a exigência de submeter o poder a normas que o limitem e disciplinem o seu exercício". A pretensão de limitação assumiu diversas formas em diferentes momentos históricos e nas diferentes formas de organização do poder. O autor mostra o desenvolvimento das ideias de soberania, representação e democracia na história do pensamento jurídico desde o Medievo.

A democracia constitui uma das "grandes palavras" do discurso político atual e passado "o seu espectro semântico é amplo e composto, e a linha de seu desenvolvimento histórico conceitual é recortada, ou até fragmentada" (COSTA, 2010, p. 211). Em outros termos, o discurso jurídico e

suas instituições acompanham as transformações sociais. É por isso que a função contramajoritária comumente atribuída ao Poder Judiciário foi fruto da tentativa de conciliação entre o poder absoluto e os direitos individuais, cuja tensão foi equilibrada pelo novo paradigma do insurgente Estado de Direito (COSTA, 2010).

O primeiro instrumento conceitual que torna pensável a síntese entre democracia e direitos

Ciências Sociais Aplicadas em Revista, v. 20, n. 38, p. 203-237, semestral, janeiro-junho, 2020. 
fundamentais - síntese esta, durante muito tempo considerada impossível - foi formulado por Kelsen. A possibilidade de que a democracia coincidisse com a tutela dos direitos fundamentais decorreu da percepção de que tanto a atividade administrativa quanto a legislativa pudessem "ser controladas por um apropriado órgão do judiciário" (COSTA, 2010, p. 253). Para Kelsen, a proteção das minorias é função essencial dos direitos fundamentais e constitui elemento fundamental para o compromisso minoria-maioria, cerne da democracia (KELSEN, 2000).

É assim que "se desenha a hipótese de um 'Estado de direito constitucional': um Estado onde tanto a atividade administrativa quanto o trabalho do legislador sejam controláveis por adequados órgãos jurisdicionais" (COSTA, 2010, p. 95). Somente no segundo pós-guerra, porém, é que esse modelo de Estado tende a se expandir, colocando a democracia como seu fundamento. No desenvolvimento do constitucionalismo, porém, a atribuição de um papel de destaque aos órgãos jurisdicionais tem seus problemas.

Se então o juiz não é o órgão de uma diafórica "razão técnica", mas é o protagonista de policies cada vez mais vastos e incisivos, subtrair-se à lógica da participação e do consenso, por um lado, torna problemática a sua legitimação, e, por outro, diminui a área de incidência daquilo que resta da democracia [...](COSTA, 2010, p. 168).

Nesse sentido Ingeborg Maus, jurista alemã, aponta o agigantamento do Poder Judiciário no continente europeu, em especial na Alemanha, após o período de duas guerras mundiais. Notase a "ampliação objetiva das funções do Judiciário, com o aumento do poder da interpretação, a crescente disposição para litigar ou, em especial, a consolidação do controle jurisdicional sobre o legislador" (MAUS, 2000, p. 185).

A veneração quase que religiosa da "Justiça" pela população se evidencia, segundo Maus, na tendência ao biografismo. Isto é, juízes escrevem suas histórias na pretensão, consciente ou não, de serem lembrados como heróis ou deuses. Essa atitude deixa a entender que a elaboração de decisões consideradas "justas" dependeria da personalidade do juiz, logo, o que conta não é o acatamento ao texto constitucional, fundamento e objeto do Judiciário, mas a correspondência dos juízes a uma ideia socialmente aceita de moral - transformada, por vezes, em moralismo (MAUS, 2000).

No Brasil, o Supremo Tribunal Federal, órgão máximo do Poder Judiciário, outrora, fora endeusado. Na atualidade, o STF é objeto de severas críticas por parte da população. Ocorre que parte considerável dessas críticas não se funda na pretensão de aprofundamento da democracia, mas na sua supressão. Os arroubos autoritários de fechamento do STF ou de ataque a ministros 
provêm desde figuras do executivo, do legislativo a setores da população.

De outro lado, há uma pretensão dos ministros de "ouvir a voz das ruas", utilizando a expressão proferida pelo ministro Luis Roberto Barroso, sem muita clareza sobre quais são essas vozes, quem pode falar e ser ouvido, como essa "voz" é identificada. Por essa pretensão, liberais e democratas também criticam essa atuação do STF, que exorbita o seu papel contra majoritário. Apesar desta pesquisa se centrar no STF, é também importante citar o papel da Lavajato na deterioração da democracia constitucional por intermédio dos usos políticos do Judiciário em detrimento das normas jurídicas.

Em suma, não faltam críticas à atuação judicial atualmente, mas existem críticas pautadas em razões autoritárias, críticas com fundamento democrático-liberal e críticas de cunho democrático-socialista. É sobre a crítica de fundamento democrático-liberal que este artigo se debruçará, uma vez que é o paradigma que informou a elaboração da constituição de 1988.

Em um plano global, desde a metade do século XX, o Poder Judiciário utiliza um sistema de valores, arbitrariamente determinados, para julgar e decidir acerca de questões que refletem a maneira como o povo ocupa os espaços sociais que lhes são originariamente legítimos. À vista disso, Maus assevera que mesmo o Poder Legislativo atua em razão do ativismo judicial, fato que inviabiliza a tomada de decisão por via democrática, já que a absorção da "nova" função jurisdicional pelo Congresso/Parlamento instaura uma onda de inércia legislativa. Ao passo que o Legislativo, de certa forma, torna-se conivente com o moralismo judicial, o Judiciário desqualifica a base social - o povo propriamente - fundamento e fim do Estado Democrático de Direito (MAUS, 2000).

O diagnóstico sobre o empoderamento do poder Judiciário foi feito também por Hischl (HIRSCHL, 2004) para quem a expansão judicial ainda ampliou o seu objeto, de modo que não apenas decisões sobre direitos, mas opera-se ainda, uma transferência massiva de questões centrais para a democracia, na medida em que conflitos políticos são tratados como questões constitucionais. As questões morais ou políticas, cedo ou tarde, se tornarão problemas judiciais. Acresce a isso a tendência a se retirar das instituições representativas a legitimidade para uma tomada de decisão.

Se o discurso implícito na maior parte das discussões a esse respeito é sempre o da democracia, o que a democracia significa hoje e qual a atual relação entre a democracia e o constitucionalismo? Outras dimensões devem ser consideradas no que reputa a função dos juízes no direito atual, especialmente no que diz respeito a troca de referências legitimadoras. A 
legitimação democrática que, em regra, se apoia em um sentido representativo, passa a se reconfigurar com o novo sentido que também é atribuído à democracia, com viés mais constitucionalizado que majoritário. A crise de legitimidade que é atribuída ao Executivo e ao Legislativo exigiu a readequação da compreensão de legitimidade e os juízes passam a funcionar como agentes primordiais de transformação social. O Estado Constitucional conduz, assim, a um Estado de juízes.

\section{A DEMOCRACIA FRENTE AO NEOCONSTITUCIONALISMO NA GLOBALIZAÇÃO ECONÔMICA}

José Eduardo Faria (FARIA, 2002) pontua que, passada a fase de implementação da globalização econômica, surge a fase de lidar com os seus efeitos jurídicos. Os conceitos de nação, Estado e soberania como conceitos elementares para a configuração do direito moderno são redesenhados. $\mathrm{O}$ autor ainda explica que essas alterações provocam uma exaustão paradigmática, na medida em que o mapa conceitual fornecido pela teoria do direito encontra dificuldades de enfrentar os atuais problemas e mostra-se incapaz de atender às suas complexidades.

Toda a engrenagem institucional é posta em xeque, na medida em que a economia se impõe sobre o debate público e o governo dos países, mais de uns que de outros. O Estado continua a exercer sua autoridade em seus limites territoriais, mas apenas em termos formais, pois muitos países não possuem condições efetivas de perseguir por si mesmos seus objetivos, sem uma autêntica autonomia decisória (FARIA, 2002). Não que a soberania esteja aniquilada, mas ela está sendo comprometida em sua base.

Haveria um confronto entre setores econômicos que exigem "desregulamentação dos mercados, a adoção de programas de desestatização, a 'flexibilização' da legislação trabalhista e a implementação de outros projetos de 'deslegalização' e 'desconstitucionalização'” (FARIA, 2002, p. 25-26), de um lado, e setores ora com defasagem tecnológica, ora com tecnologia de fronteira que dependem de uma maior atuação estatal.

Isso o conduz a questionar o papel a ser exercido por uma Constituição-dirigente, como o pretende ser a Constituição de 1988. A Constituição brasileira foi escrita num período de turbulência econômica. No Brasil, segundo José Eduardo Faria (FARIA, 2010), a constitucionalização está situada no marco não apenas da democratização e transição política, mas de uma constituição que passa a compreender direitos e garantias sociais e constitucionais num

Ciências Sociais Aplicadas em Revista, v. 20, n. 38, p. 203-237, semestral, janeiro-junho, 2020. 
momento voltado para estabilização econômica. Todas essas condições sociais e políticas põem em questão a efetividade dos direitos.

Aliás, falar hoje em constituição dirigente sem se atentar para o fenômeno que Bercovici denomina de constituição dirigente invertida, que se define pela dissociação entre a supremacia da constituição financeira, destinada à garantia do capital privado e do equilíbrio macroeconômico, em detrimento da concretização da constituição econômica. A Emenda Constitucional 95/2016 escancara a realidade de uma constituição dirigente invertida. Trata-se de sobrepor a constituição financeira à constituição econômica. O que se percebe, nesse cenário, é que o temor à democracia representada pela soberania popular é ainda o que acompanha esses discursos em favor do protagonismo judicial.

\begin{abstract}
Afinal, a ingovernabilidade, para os neoliberais, é gerada pelo excesso de democracia. Do mesmo modo que o Estado, a constituição demonstra uma crescente debilidade intrínseca, com cada vez menos capacidade de regular a política e a economia. A constituição, que deveria ser o controle político do poder econômico, vê os poderes que deveria controlar se tornarem ocultos e inalcançáveis. Este fenômeno de neutralização econômica do Estado e de proteção constitucional reforçada para instituições econômicas, colocando-as a salvo de qualquer interferência política democrática é denominado de 'neoconstitucionalismo econômico' ou economic constitutionalism'. [...] O ativismo ampliado dos tribunais, inclusive, tem servido muito mais para preservar a ordem do mercado e limitar o poder de atuação do Estado do que para garantir ou ampliar direitos fundamentais (BERCOVICI, 2008, p. 335).
\end{abstract}

Acresce a isso o fato de que a concretização dos direitos depende em maior medida do Judiciário. Isso não apenas pelo corporativismo das demandas que prosperam no Judiciário, mas em função da desigualdade de acesso à Justiça que vai desde a possibilidade de que algum direito chegue efetivamente ao Judiciário por pessoas com poucos recursos financeiros e culturais, até o momento em que o acesso é comprometido na medida em que variáveis extrínsecas e que exercem papel determinante para o sucesso da demanda judicial, tais como o tempo e o dinheiro, são elementos cujo acesso é desigual.

\title{
3.1 A TENDÊNCIA AO PÓS-POSITIVISMO
}

O pós-positivismo ${ }^{3}$ aparece na cena jurídica brasileira justamente nesse contexto de

\footnotetext{
${ }^{3}$ Importante destacar que, neste artigo, por uma questão prática, uma vez que a diferenciação entre estes termos diverge a depender do referencial teórico utilizado, "neoconstitucionalismo" e "pós-positivismo" serão utilizados como sinônimos.
}

Ciências Sociais Aplicadas em Revista, v. 20, n. 38, p. 203-237, semestral, janeiro-junho, 2020. 
globalização econômica. Dimoulis afirma existirem duas tendências atualmente. A primeira apresenta uma posição idealista, ou seja, percebe influências do jusnaturalismo e procura estabelecer uma conexão entre o Direito e ideais como "bem comum", "justiça" e "moralidade". Já a segunda tendência, de feição sociológica, pretende assentar a ideia de que o Direito necessita se adequar aos parâmetros da sociedade atual. Logo, defende maior discricionariedade dos juízes para fazer jus a uma interpretação mais flexível das normas, por vezes, contra e além do texto legal. Essas duas tendências são, frequentemente, atreladas à expressão "pós-positivismo", reivindicada pelos críticos do juspositivismo (DIMOULIS, 2006).

Dimoulis observa que o termo "pós-positivismo" é pouco usado fora do ambiente brasileiro. Existem algumas citações entre os juristas alemães que compõem a teoria estruturante do Direito, cujo expoente é Friedrich Müller. Tal teoria reivindica uma metodologia pós-positivista do direito, tendo como significado a necessária consideração de aspectos históricos e sociais quando da concretização das normas jurídicas. Desse modo, o intérprete do texto legal precisa assumir um papel ativo, a fim de conferir sentido à norma jurídica. Todavia, Müller admite a imprescindível vinculação às normas jurídicas estatais e, nessa toada, rejeita a abordagem antipositivista que pretende “(...) transformar o aplicador em 'legislador oculto”" (DIMOULIS, 2006, p. 48). Isto é, critica, ferrenhamente, o moralismo presente em diversas das teorias denominadas pós-positivistas.

No Brasil, o pós-positivismo difundido representa a fusão de posições adotadas por autores como Robert Alexy e Ronald Dworkin. Nesse sentido, nota-se a presença de aspectos moralistas e idealistas nas diversas abordagens ditas pós-positivistas pelos autores brasileiros. Contudo, a definição de autores - Dworkin, por exemplo - como pós-positivistas torna-se inadequada sob o ponto de vista substancial. Dessa maneira, "antipositivista” é a expressão mais compatível com o conteúdo das perspectivas adotadas pelos juristas brasileiros. Outrossim, a utilização de "póspositivismo" pautada no critério cronológico também não se sustenta, visto que muitas das críticas ao positivismo jurídico são anteriores às formulações positivistas que prevalecem atualmente (DIMOULIS, ${ }^{2006}$ ).

As abordagens pós-positivistas no Brasil concentram-se em elementos como "justiça", "verdade", "moral”, "dignidade humana" - expressões caracterizadas por uma alta carga valorativa que permite ao juiz ampla discricionariedade na aplicação da norma jurídica. Nesse sentido, autores adeptos dessa teoria asseveram a necessidade de ter em vista, constantemente, o compromisso com a justiça, ainda que signifique a desconsideração de normas válidas e o abalo da segurança jurídica. Entretanto, não há a indicação dos métodos que permitam encontrar a solução justa a cada caso. 
Logo, o protagonismo é dos juízes, visto que "justiça” é um conceito relativo. A consideração do que é justo, de acordo com a moral ou ética varia, sob essa perspectiva, segundo o intérprete da norma, de modo que os textos legais cujo objetivo seria atuar como garantia aos indivíduos já não são mais observados dessa maneira (DIMOULIS, ${ }^{2006}$ ).

\subsubsection{O neoconstitucionalismo em terras brasileiras}

Como forma de explicitar a adoção do pós-positivismo no Brasil, pode-se citar as considerações de Luis Roberto Barroso. Barroso afirma que o neoconstitucionalismo surge a partir do constitucionalismo caracterizador do período pós-segunda guerra mundial, no qual países como Alemanha e Itália, apresentam-se como terreno fértil ao protagonismo do "Estado Democrático de Direito" (BARROSO, 2012).

Esse momento corresponde, em território nacional, à redemocratização brasileira, após o período de autoritarismo da ditadura militar, simbolizado, principalmente, pela promulgação da Constituição da República Federativa do Brasil de 1988. Barroso considera que a CRFB/1988 foi o instrumento pelo o qual o maior período de estabilidade democrática brasileira pôde ocorrer. A promulgação desse documento elevou o direito constitucional a patamar superior na hierarquia do ordenamento jurídico brasileiro. A constituição de 1988 estimulou o que Barroso chama de "sentimento constitucional" no povo, refletido na esperança de alcançar objetivos antes impossíveis de serem se quer almejados (BARROSO, 2012). Atenta-se aqui para a tendência pós-positivista de explorar a utilização de termos que invoquem emoções e provoquem a catarse do público-alvo.

O pós-positivismo, segundo Barroso, encontra-se na intersecção do jusnaturalismo e do positivismo estrito, na medida em que não despreza o direito posto, mas recorre a categorias valorativas como a moral. O neoconstitucionalismo, portanto, nessa perspectiva filosófica, aproxima o Direito da moral, buscando elaborar uma teoria da justiça e dos direitos fundamentais, esses pautados na dignidade da pessoa humana (BARROSO, 2012).

Sob o ponto de vista teórico, o novo direito constitucional molda-se a partir de três momentos distintos. O primeiro deles é o reconhecimento da força normativa dos preceitos constitucionais durante o século XX. ${ }^{4}$ À medida que ocorre a constatação da imperatividade das

\footnotetext{
${ }^{4}$ Pode-se realizar uma crítica no que concerne à reivindicação do reconhecimento da força normativa dos preceitos constitucionais pelo pós-positivismo. Na verdade, no século XIX, mais especificamente com relação às Constituições surgidas na Europa e na América Latina, já havia a percepção de superioridade das constituições em comparação com a legislação ordinária (NOVAIS, 2016).
} 
normas constitucionais, observa-se a presença de seus próprios mecanismos de coerção na hipótese de descumprimento. Barroso assevera que até a década de 80 , as constituições brasileiras foram mais um aglomerado de promessas do que um verdadeiro compromisso democrático com o povo (BARROSO, 2012).

O segundo momento do marco teórico do direito constitucional foi, justamente, a expansão de sua jurisdição pela Europa na década de 1940, representada, em grande medida, pela supremacia da Constituição e pela criação de Tribunais Constitucionais. No Brasil, essa expansão da jurisdição constitucional acontece com a CRFB/1988, além da ampliação do direito de propositura a partir da criação de mecanismos como a ação declaratória de constitucionalidade e a arguição de descumprimento de preceito fundamental (BARROSO, 2012).

Como terceiro momento, a hermenêutica jurídica é deveras influenciada pela perspectiva constitucional. Estabelecem-se alguns princípios interpretativos constitucionais: "o da supremacia da Constituição, o da presunção de constitucionalidade das normas e atos do Poder Público, o da interpretação conforme a Constituição, o da unidade, o da razoabilidade e o da efetividade" (BARROSO, 2012, p. 8). Dentre tais princípios, destacam-se o da unidade da Constituição e o da interpretação conforme a Constituição, na medida em que buscam, respectivamente, construir uma sistemática dentro e em torno da constituição e a compatibilidade entre as normas constitucionais e entre essas e as regras infraconstitucionais.

Dessa forma, erige-se uma nova interpretação constitucional, a qual é caracterizada por dois aspectos importantes: o papel da norma e o papel o juiz. De acordo com Barroso (BARROSO, 2012), no que concerne à norma, a solução dos problemas fáticos nem sempre estará contida na regra constitucional, de modo que seria necessário ir além do texto normativo. O papel do juiz, nesse sentido, é modificado, na medida em que se torna um co-legislador, ao valorar as normas abrangentes e escolher dentre as soluções possíveis a que julga ser mais adequada ao caso concreto. Barroso identifica, no âmbito da nova interpretação, diversos conceitos importantes, tais como: cláusulas gerais, princípios, colisões de normas constitucionais, ponderação e argumentação.

Uma das marcas do pós-positivismo é a diferença entre regra e princípio, mais explorada por Robert Alexy. Desse modo, segundo Barroso: “princípios não são, como as regras, comandos imediatamente descritivos de condutas específicas, mas sim normas que consagram determinados valores ou indicam fins públicos a serem realizados por diferentes meios" (BARROSO, 2012). A partir dessa definição de princípios como "mandamentos de otimização" para utilizar a expressão de Alexy, o juiz teria mais liberdade em sua atuação, posto que os princípios proporcionariam maior 
discricionariedade (ALEXY, 2017). Insere-se aqui uma crítica relevante quanto a essa diferenciação difundida pelo pós-positivismo, na medida em que se questiona se taxar uma norma como princípio não seria um artifício para relativizar direitos e garantias fundamentais.

Barroso afirma que, com o reconhecimento das normas como gênero, do qual fazem parte as regras e os princípios, inevitável tornou-se a colisão entre normas constitucionais, a qual não pode ser resolvida pelos métodos tradicionais de solução de antinomias jurídicas. É nesse ambiente, que a ponderação aparece como o critério mais adequado à resolução de tais colisões. A ponderação estabelece o sopesamento das normas constitucionais em conflito e determina qual delas irá se sobressair no caso concreto a partir uma dinâmica de concessões mútuas (BARROSO, 2012). Um dos mais expressivos posicionamentos do STF, por exemplo, tem íntima relação com essa técnica de solução de conflito, a saber, a dialética entre a reserva do possível e o mínimo existencial.

Sob a ótica neoconstitucionalista, nos casos difíceis - assim entendidos aqueles que comportam mais de uma solução possível - a atuação do juiz deve ser, sobretudo, minuciosamente fundamentada. Nesse sentido, a remissão da decisão adotada a uma das normas componentes do sistema jurídico torna-se fundamental. Inegável é, logo, o aumento da atividade criativa dos juízes nessa conjuntura. No entanto, ao procurar uma norma para pautar suas decisões, os magistrados, por vezes, podem ancorar-se em mutações constitucionais (estratégias que podem ser observadas sob um ponto de vista problemático a partir da perspectiva do positivismo jurídico).

Ainda, Barroso defende que na esfera do pós-positivismo, as decisões jurisdicionais devem ater-se às consequências que geram no mundo dos fatos. Desse modo, o juiz, no exercício de sua função, precisaria realizar a jurisdição de acordo com os possíveis resultados práticos de suas decisões (BARROSO, 2012). Todavia, pode-se questionar sobre se o Judiciário dispõe de meios e condições para aferir o resultado social de suas decisões. Algo difícil de ser aferido até mesmo por sociólogos, antropólogos e outros cientistas sociais. A própria configuração e constituição dos tribunais e do judiciário busca garantir que ele atenda a critérios jurídico-técnicos.

Percebe-se, a partir das considerações de Barroso, que o neoconstitucionalismo no Brasil pauta-se em uma versão do pós-positivismo que congrega tanto a sua visão pragmática quanto moralista. Ademais, tenta lidimar suas teorias atacando o positivismo jurídico, uma vez que este estaria "ultrapassado". 


\subsection{A FRAGILIDADE DA LEGITIMAÇÃO DO PÓS-POSITIVISMO}

A fim de legitimar uma teoria pós-positivista, os críticos do positivismo jurídico procuram construir-lhe uma imagem caricatural. O positivismo é apresentado de maneira que não corresponde ao conteúdo da produção jurídica de diversos autores juspositivistas ao longo do século XX. Na maior parte das vezes, se recorre a uma descrição do positivismo exegético do século XIX, que não é defendido atualmente por nenhuma corrente positivista. A utilização desse tipo de artifício, qual seja, a elaboração de um "espantalho", já denuncia a fragilidade da fundamentação que sustenta o pós-positivismo brasileiro (DIMOULIS, 2006).

$\mathrm{O}$ argumento estabelecido pelos antipositivistas assenta-se em três premissas. A primeira é de que os positivistas fazem uma aplicação mecânica da lei. O positivismo, segundo essa posição, limita a atividade do juiz, vez que a ele só é concedido o poder de aplicar a norma ao caso por meio de uma dedução lógica. Isso reduz a função do magistrado a mero aplicador da lei e não condiz com as teses das mais importantes obras para o positivismo jurídico, como é o caso da "Teoria Pura do Direito" de Hans Kelsen (KELSEN, 2009).

Segundo Kelsen, a teoria tradicional da interpretação crê que esta deveria, além de fornecer a moldura do Direito a ser aplicado, definir uma única "solução correta" para os casos de indeterminação. Entretanto, de acordo com o autor, não existem métodos de interpretação que conduzam a uma única "solução correta", bem como não existem critérios para definir a preferência por um meio de interpretação frente a outro ou em quais circunstâncias devam ser aplicados. Dessa forma, o que se pode fazer frente às indeterminações do direito a aplicar é escolher uma das possibilidades compreendidas na moldura, uma vez que todas terão o mesmo valor jurídico sob o ponto de vista do Direito Positivo (KELSEN, 2009).

À vista disso, o jurista afirma que a interpretação de uma lei pelos órgãos aplicadores do Direito compõe-se de um ato de conhecimento e de um ato de vontade. Isto é, quando o órgão aplicador do Direito, a partir de uma interpretação cognoscitiva, fixa a moldura do Direito a aplicar, toma conhecimento das várias possiblidades de soluções para a indeterminação analisada. Nesse sentido, a interpretação refletiu um ato de conhecimento do Direito Positivo. No entanto, o órgão aplicador também deve escolher, dentre as várias possibilidades que habitam a moldura, uma solução para o caso. Dessa maneira, ao escolher uma opção, o órgão aplicador realiza um ato de vontade, com o qual se produzirá uma norma inferior ou será executada uma sanção (KELSEN, 2009).

Ciências Sociais Aplicadas em Revista, v. 20, n. 38, p. 203-237, semestral, janeiro-junho, 2020. 
Kelsen estabelece que a interpretação do Direito pelo órgão que o aplica sempre cria Direito, visto ser ela autêntica. Destarte, o juiz também realiza atividade criativa na teoria juspositivista. Tanto é que o jurista reconhece a possibilidade de haver decisões fora da moldura jurídica (KELSEN, 2009).

Nessa mesma linha de pensamento, outros juristas positivistas se posicionam a exemplo de H. L. A. Hart, cuja análise da textura aberta do Direito percebe diferentes espaços amplos de discricionariedade do aplicador da norma. Outrossim, Joseph Raz admite a possibilidade legítima de os juízes criarem Direito quando não há expressa previsão legal (DIMOULIS, 2006).

A segunda premissa levantada pelos pós-positivistas a fim de descaracterizar o positivismo jurídico é de que este pregaria a validade da norma acima de tudo. Uma norma seria considerada justa na medida em que fosse válida, sem que o seu conteúdo seja analisado. No entanto, Dimoulis afirma que são pouquíssimos os autores ditos positivistas que adotam uma postura de equiparação entre validade e legitimidade. Ademais, com relação a esses poucos autores o seu pertencimento à corrente positivista é questionado (DIMOULIS, 2006).

A terceira premissa é que conhecidos autores positivistas seriam incoerentes em suas análises, ao adotarem elementos pertencentes ao jusnaturalismo. Essa alegada incoerência é levantada pelos pós-positivistas para desqualificar o positivismo. Juristas como Hart, Kelsen e Ross são acusados de tal incoerência, todavia, Dimoulis (DIMOULIS, 2006) assevera que tal acusação só poderia ser discutida talvez com relação a Hart, visto que Kelsen e Ross rejeitam expressamente os parâmetros do jusnaturalismo em suas obras.

Uma outra crítica feita ao positivismo jurídico diz respeito a sua não adoção da principiologia. A diferenciação entre princípios e regras, deveras difundida no ambiente brasileiro afirma que os princípios seriam "abstratos e vagos" e que teriam finalidades meramente programáticas. A partir dessa tese, pode-se questionar, novamente, se taxar uma norma como princípio não seria um artifício para relativizar direitos e garantias fundamentais. Dimoulis (DIMOULIS, 2006), considera, portanto, que a diferença entre regra e princípio é somente quantitativa, na medida em que neste o aplicador goza de maior discricionariedade que, no entanto, deve ser tendente à concretização do referido direito.

O que se depreende das reivindicações pós-positivistas no Brasil é que elas se apresentam muito mais como um pretexto para a discricionariedade dos juízes do que para a realização de qualquer das expressões valorativas que dizem perseguir. Trata-se, portanto, de uma tentativa de liberar os intérpretes dos limites estabelecidos pela lei. A decisão que essa postura produzirá poderá 
ou não ser considerada compatível. Neste último caso, as consequências de tal ato podem, por vezes, colocar em xeque as estruturas do Estado de Direito.

Outrossim, segundo Maus, existem dois obstáculos para a viabilidade do neoconstitucionalismo: a "extrema generalidade da ótica da moral, em oposição às normas jurídicas [...]" e "[...] a relação indeterminada entre a moral atribuída ao direito e as convicções morais empíricas de uma sociedade” (MAUS, 2000, p. 186). A fim de sanar esses problemas, os juízes deveriam filtrar a "moral da comunidade", dando ares de uma decisão imparcial. Entretanto, são os próprios juízes que determinam a moral que lhes convém. A justiça transforma-se, assim, em instância moral, o que faz com que o Judiciário não seja fiscalizado pelo controle social e, consequentemente, a democracia se veja ameaçada (MAUS, 2000).

Dessa forma, com o agigantamento do Poder Judiciário, as garantias antes previstas tornamse incertas, visto que dependem de decisões judiciais e do personalismo de juízes. Com efeito, o âmbito do que é proibido aumenta e é deturpada, consequentemente, a tônica de liberdade individual. A tendência neoconstitucional, nessa toada, permite que as decisões sejam desvinculadas da legalidade. A desvinculação do texto constitucional é, entretanto, segundo Maus, revestida de confiança popular, que, imbuída de um sentimento de veneração, beirando ao infantilismo, acredita na neutralidade e imparcialidade do Poder Judiciário (MAUS, 2000).

Entende-se, portanto, que o texto de Maus, assim como as observações de Dimoulis, é relevante, pois além de estar presente em boa parte dos textos que apresentam a crítica ao moralismo judicial, tornado possível no contexto do neoconstitucionalismo, ele também coloca como centro de sua reflexão a soberania popular. As considerações sobre a jurisdição constitucional partem de parâmetros democráticos, mas que tipo de democracia está sendo defendida aqui é o elemento que balizará a reflexão nesta pesquisa.

\subsection{A PROPENSÃO À JUDICIALIZAÇÃO DA POLÍTICA}

Existe uma diferenciação doutrinária entre judicialização e ativismo judicial. A transferência da decisão acerca de questões com ampla repercussão política e social para as esferas do Poder Judiciário é o que se chama de judicialização. Ocorrem mudanças na forma de argumentação, na linguagem e na dinâmica de participação política quando, ao invés das instâncias democráticas, a exemplo do Poder Legislativo, é o Judiciário que resolve tais demandas. Esse fenômeno decorre do modelo constitucional adotado. À medida que algo é regulamentado na 
constituição, surge uma demanda judicial, da qual o Judiciário não pode se esquivar. Logo, judicialização não significa exercício deliberado da vontade política. Ela decorre da vontade do próprio constituinte e permite, assim, que discussões de elevando alcance político e moral apareçam à sociedade por intermédio de ações judiciais (BARRROSO, 2012).

De outro lado, o ativismo judicial orienta-se para uma postura mais intervencionista do Poder Judiciário, que interfere nas esferas dos outros poderes do Estado. Essa atuação pode ser concretizada de três formas: ao aplicar as normas constitucionais diretamente a casos não expressamente previstos pelo legislador ordinário; a declaração de inconstitucionalidade realizada sobre atos normativos do Poder Legislativo por meio de critérios menos rígidos; e a imposição de condutas ou omissão ao Poder Público quanto à realização de políticas públicas.

Em contraposição ao ativismo, tem-se a autocontenção judicial, cujo conteúdo reflete uma posição do Judiciário bem menos intervencionista no que se refere ao campo de atuação dos outros Poderes. Logo, são três orientações que estruturam a atividade jurisdicional nesse caso: não há a aplicação direta da Constituição a casos que o legislador não previu expressamente; utilizamse critérios mais rígidos para declarar a inconstitucionalidade de uma lei e não se interfere na realização ou organização de políticas públicas. ${ }^{5}$

Também necessário atentar-se para a judicialização da política. Com efeito, a conjuntura de agigantamento da atuação judicial, com a existência cada vez maior de normas carregadas de conteúdo axiológico e que constituem o aparato normativo que confere ao juiz ampla possibilidade de atuação nos limites (ou fora deles) hermenêuticos, conduz ao paradigma de judicialização da política que, no âmbito de relativização da moldura, torna-se difícil diferenciar a judicialização do ativismo.

De acordo com Vianna, Burgos e Sales (VIANNA; BURGOS; SALLES, 2007), pode-se dizer que a extrapolação das funções do Poder Judiciário a esferas típicas do debate político teve início no pós-segunda guerra, momento em que o acréscimo de texto dogmático e valorativo nas constituições dos Estados era visto como forma de condicionar a atuação de seus representantes. A alavancada do Welfare State permitiu maior liberdade do juiz, na medida em que se torna um "legislador implícito". Os autores consideram que o Estado de bem-estar social, quando se define

\footnotetext{
${ }^{5}$ Entretanto, é necessário fazer ressalvas acerca dessa diferenciação. As distinções entre judicialização e ativismo estabelecidas pela doutrina carecem de uma base teórica sólida, uma vez que não são definidos parâmetros de análise do que seria judicialização e do que constituiria ativismo. Os limites entre esses dois fenômenos são muito tênues, e a doutrina não dá conta de explicar, praticamente, o que permitiria a classificação dos casos como expressão de um ou de outro. Ademais, vale ressaltar que, segundo Dimoulis e Lunardi, não há uma definição histórica consistente do que seria ativismo judicial, termo utilizado segundo diversos critérios a depender do autor que dele faz uso.
}

Ciências Sociais Aplicadas em Revista, v. 20, n. 38, p. 203-237, semestral, janeiro-junho, 2020. 
pela inclusão de princípios fundamentais no texto constitucional, confere à atividade jurisdicional a tarefa de definir os conceitos abstratos que os direitos e garantias expressos na constituição carregariam.

Ocorre que a maior atuação do poder judiciário se dá com a crise do Estado de bem-estar social por volta dos anos 1970 e surgimento do neoliberalismo: forte desregulamentação do mercado e esvaziamento do núcleo social das constituições. Ao passo que os direitos e garantias fundamentais retraem-se na esfera do legislativo, a população busca o Judiciário como última e única espaço para a afirmação de seus direitos (VIANNA; BURGOS; SALLES, 2007).

No Brasil, como reflexo da modernização ocorrida nos anos 1930, amparada, principalmente, no direito administrativo, a redemocratização contará não com um projeto jurídico novo, mas com a ideia de reformar a antiga tradição republicana brasileira. Dessa forma, foram retirados os elementos autoritários do texto constitucional de 1988 e deu-se ênfase aos direitos e garantias relacionados à cidadania e às liberdades típicas da primeira dimensão de direitos fundamentais, expressão do liberalismo (VIANNA; BURGOS; SALLES, 2007).

Procurado também como principal garantidor de direitos, o Poder Judiciário no Brasil vai se estabelecer como mais relevante instrumento de defesa das minorias políticas, por meio, principalmente, do controle de constitucionalidade. As Ações Diretas de Inconstitucionalidade, segundo Vianna, Burgos e Sales tornaram-se prerrogativas de governo. Essas ferramentas são utilizadas, ao tomar por base o período desde o ano 1988, como meio indispensável ao fazer político. É nesse sentido que se observa a judicialização da política no Brasil (VIANNA; BURGOS; SALLES, 2007).

De acordo com os autores (VIANNA; BURGOS; SALLES, 2007), as ADI's são utilizadas por diversos setores da sociedade e apresentam-se tão arraigadas na cultura política nacional que o país se reduz à ingovernabilidade na ausência delas. Na análise de cerca de 3.648 ADI's entre 1988 e 2005, constatou-se um número massivo de ações que versam sobre a administração pública (quase $60 \%$ do total). Por meio dessas ações, pode ser observado um incentivo à tendência centralizadora que circunda a história brasileira.

Nessa perspectiva, o controle de constitucionalidade auxilia na homogeneização da produção legislativa estadual e coloca a União acima dos interesses dos estados, o que fere o pacto federativo, visto que nenhum dos entes é superior hierarquicamente. A relação de submissão entre União e federação, característica da centralização política e administrativa, presente em todos os períodos autoritários do país, é utilizada para incentivar a realização de reformas que buscam 
justificativa em uma "vontade política nacional" que, na verdade, não existe. Vianna, Burgos e Sales afirmam, nesse sentido, que:

A democratização do país em 1985 - em boa parte resultante das forças federativas em oposição ao governo unitário e centralizador do regime militar - paradoxalmente tem implicado tendências ao retorno de um estilo centralizador que não pode mais ser ignorado (VIANNA;BURGOS;SALLES, 2007, p. 45).

A pesquisa realizada pelos autores aponta que o número de ADI's propostas e os autores de tais ações mudam consideravelmente de acordo com o alinhamento político dos governos no âmbito federal. Observa-se que, durante governos de direita, a exemplo de Fernando Henrique Cardoso, as ações foram apresentadas, majoritariamente, por partidos políticos e associações consideradas de esquerda. Ao contrário, nos governos Lula, as ações foram realizadas por governadores e procuradores, de forma majoritária, e por partidos políticos de direita (VIANNA; BURGOS; SALLES, 2007).

Os autores consideram, dessa maneira, que a utilização do sistema de controle de constitucionalidade tornou-se prática institucionalizada tanto na política praticada pelos partidos de esquerda e associações de trabalhadores, quanto na atuação de governadores e procuradores (VIANNA;BURGOS;SALLES, 2007). Não obstante o emprego das ações de inconstitucionalidade também pelos partidos políticos de direita, Vianna, Burgos e Sales aferem que essa é uma constante dos partidos de esquerda. Resta questionar se a utilização desse tipo de mecanismo não constitui uma falha da esquerda brasileira, na medida em que tenta suprir a falta de mobilização social, recorrendo ao Judiciário.

\section{AS CONTRIBUIÇÕES DE JEREMY WALDRON}

Em "A dignidade da legislação", Waldron procura mostrar que, embora a teoria constitucional costume pintar um quadro desfavorável do Legislativo, os problemas e desvios a que estão sujeitos os seus integrantes também estão os do Judiciário. "Construímos, então, um retrato idealizado do julgar e o emolduramos junto com o retrato de má fama do legislar" (WALDRON, 2003, p. 2). Diante de uma teoria da legislação empobrecida e subteorizada, Waldron elabora uma teoria que dignifique a função legislativa exercida pela instituição que se organiza e se destina a modificar deliberadamente as leis. 
As contribuições de Waldron são particularmente importantes no contexto brasileiro, uma vez que o Legislativo jamais teve condições de se afirmar como central. A ideia de um Estado de Direito que coloca o Legislativo no centro nunca se afirmou com tanta tranquilidade no Brasil, pois, ora tivemos a predominância de um Executivo forte, ora de um Judiciário ativista.

Waldron (WALDRON, 2003) questiona o motivo pelo qual se tem uma tendência de se priorizar instituições que negam ou escondem a sua atividade legislativa, como se houvesse uma suspeita em relação ao explícito e ao deliberado na política, o que enfraquece a transparência da legislação. Ademais, os tribunais são tratados como apolíticos e técnicos, como se fossem um espaço de sábios. No Brasil, há um Supremo que atua como legislador sem dizer explicitamente que o faz e que se apresenta como uma espécie de casa revisora do Legislativo que aplaca os delírios de um poder apresentado como não muito racionalizado.

Para pensar essas questões importa retomar e questionar a visão da constituição como précompromisso. Ela parte de alguns pressupostos sobre de constituição, povo e democracia que precisam ser aprofundados e recolocados. A uma concepção diacrônica de povo, concebido como ente abstrato, Jeremy Waldron apõe uma concepção sincrônica. Isso significa reconhecer a pluralidade da ideia de povo, que compreenda a sua diversidade e mesmo o desacordo. Quanto à constituição, ele propõe uma definição de vai além das restrições que a constituição impõe, pois o seu papel seria mais o de fortalecer a democracia que restringi-la. Por fim, no que diz respeito à democracia, ele defende que, se o povo é titular de direitos, ele é também autônomo para tomar decisões e se autogovernar.

Para Waldron, deve-se reconhecer a existência de desacordos genuínos diante de questões morais complexas: essa é uma característica das sociedades modernas. Esse reconhecimento leva ao debate sobre como eles devem ser resolvidos. Nesse contexto, perceber as pessoas como sujeitos de direitos é admitir a sua capacidade, isso decorre da "convicção de que homens e mulheres são plenamente capazes de participar de forma responsável no governo de sua sociedade" (WALDRON, 2003, p. 251).

De modo geral, Waldron (2016) pretende problematizar certos pressupostos do debate em favor do constitucionalismo, como a ideia de consenso político. Quando os direitos restam entrincheirados nas constituições, o debate político é retirado do espaço público. Waldron, defende, portanto, o reconhecimento da política como conflito. Também revisa a concepção comum que costuma reconhecer como democracia verdadeira a democracia direta, de modo que a democracia representativa seria um desvio ou inconveniente. Ao contrário, ele defende que a democracia 
representativa é algo a ser perseguido. $\mathrm{O}$ argumento da crise do modelo político-representativo brasileiro deu amparo para que o Judiciário fosse alçado à condição de protagonismo no cenário político, ocorre que as críticas feitas às instituições representativas e que permitem o agigantamento do Poder Judiciário partem de certos conceitos que Waldron desconstrói.

Refinar os conceitos, como exigência do objeto de estudo significaria um ganho em clareza analítico-conceitual. Nesse sentido, a teoria política de Waldron é um referencial importante. Não para se transplantar discussões pensadas para outros contextos e realidades e aplicá-las no Brasil, mas para que sirva como fonte de um diálogo para se pensar a realidade brasileira e seus respectivos problemas.

\subsection{A (DES)NECESSIDADE DO CONTROLE JUDICIAL SOBRE A ATIVIDADE DO PODER} LEGISLATIVO

Em outro ensaio, Jeremy Waldron, ao analisar a atuação do poder judiciário nos Estados Unidos - principalmente no que concerne à prática do judicial review, realizado sobre a legislação, pela Suprema Corte - assinala que o controle feito pelos tribunais sobre o exercício da função legislativa é incompatível com uma sociedade livre e democrática. Pautado em algumas premissas, o autor demonstra a desnecessidade do protagonismo judicial no que se refere às decisões que poderiam e deveriam ser elaboradas por uma via democrática, seja no âmbito do legislativo ou por outro meio consoante ao respeito à soberania popular como fundamento e propósito do Estado (WALDRON, 2010).

Inicialmente, pode-se afirmar que o apoio ao judicial review vincula-se a decisões específicas (a exemplo da recente criminalização da homofobia e da transfobia pelo STF no Brasil). Desse modo, é comum que as pessoas procurem formar uma opinião acerca da atuação do poder judiciário tomando por base o conteúdo das decisões em pauta. Faz-se um juízo de valor sobre o resultado obtido, no entanto, são os procedimentos utilizados para a sua obtenção que importam quando se questiona a legitimidade do judicial review (WALDRON, 2010).

Uma indagação necessária para enfrentar a tendência pós-positivista é se a revisão judicial realmente discute a essência do problema. Waldron acredita que os debates nos tribunais tangenciam o verdadeiro conflito de direitos levados à tutela. Para o autor, o judicial review afasta do campo democrático a resolução de questões que afetam diretamente os cidadãos (sujeitos da democracia) ao levar o foco para aspectos referentes a precedentes - jurisprudência no caso

Ciências Sociais Aplicadas em Revista, v. 20, n. 38, p. 203-237, semestral, janeiro-junho, 2020. 
brasileiro - doutrina e interpretação, elementos distantes do cotidiano das pessoas. Relegar a um pequeno número de indivíduos não eleitos e não passíveis de responsabilização a decisão acerca de direitos fundamentais dos indivíduos é, sob o ponto de vista democrático, "politicamente ilegítimo" (WALDRON, 2010, p. 98).

À vista disso, o autor estabelece quatro pressuposições para fundamentar o argumento em oposição ao judicial review, uma vez que esse é condicional, ou seja, depende da satisfação das premissas. ${ }^{6}$ De acordo com Waldron, portanto, devem ser satisfeitas as seguintes pressuposições:

[...] (1) instituições democráticas em condições de funcionamento razoavelmente boas, incluindo um legislativo representativo, eleito por sufrágio adulto universal; (2) um conjunto de instituições judiciais, também em boas condições de funcionamento, erigidas sobre uma base não representativa para conhecer de ações individuais, resolver controvérsias e defender o Estado de direito; (3) um comprometimento da parte da maioria dos membros da sociedade e da maioria de suas autoridades com a ideia de direitos individuais e de minorias e (4) discordância persistente, substancial e de boa-fé quanto a direitos (isto é, quanto ao que realmente significa o comprometimento com direitos e quais são suas implicações) entre os membros da sociedade que estão comprometidos com a ideia de direitos (WALDRON, 2010, p. 106).

Quanto à primeira pressuposição, deve-se pensar em uma sociedade democrática, na qual as leis e políticas públicas são determinadas com participação do povo, direta ou indiretamente - a partir de representantes eleitos. O sistema político de tal sociedade deve ser democrático em diversas esferas, com voto adulto universal exercido em eleições periódicas e imparciais a fim de estabelecer um legislativo representativo. Concernente ao parlamento, ele deve ser um órgão deliberativo composto por muitas pessoas, que discutem e votam questões importantes referentes à política social (WALDRON, 2010).

O Poder Legislativo ${ }^{7}$, nesse contexto, apresenta certas garantias para manter o seu bom desempenho, a exemplo das comissões parlamentares e do bicameralismo. Sob esse ponto de vista, os congressistas se veem, por vezes, como verdadeiros representantes dos eleitores e consideram suas opiniões, embora de maneira genérica, como parâmetros para a elaboração de leis que afetam

\footnotetext{
${ }^{6}$ Cabe destacar que, não obstante a crítica de Waldron ser de cunho universalista, o contexto em que ela foi desenvolvida é de um Direito baseado na common law, desse modo, é necessário refletir até que ponto ela se adequada aos parâmetros da civil law constantes no panorama jurídico brasileiro.

${ }^{7}$ É importante destacar que essa relação entre o Judiciário e o Legislativo é apenas um dos focos possíveis de análise. Geralmente se destaca a relação entre o Executivo e o Legislativo a partir das discussões do presidencialismo de coalizão. Embora não seja objeto deste estudo, a relação entre o Executivo e o Legislativo também é importante, sobretudo levando-se em consideração a definição da agenda do Legislativo promovida pelo Executivo, que está em torno de 85\%: "Mais de 85\% de toda a legislação adotada desde 1985 teve sua origem no Poder Executivo" (POWER, 2015, p. 19).
}

Ciências Sociais Aplicadas em Revista, v. 20, n. 38, p. 203-237, semestral, janeiro-junho, 2020. 
diretamente os interesses dos cidadãos. Ademais, a filiação partidária é fundamental para definir o posicionamento político dos legisladores, além de apresentarem de forma mais coesa os diversos direcionamentos que podem ser seguidos pelos eleitores ao exercerem seu direito ao voto (WALDRON, 2010).

Desse modo, a pressuposição é de que as instituições democráticas como a Câmara dos Deputados e o Senado Federal estejam funcionando, no mínimo, razoavelmente bem. Tal suposição não significa que as instituições são perfeitas. É possível que haja, em algum momento, ameaças à igualdade de representação, contudo, o parlamento/congresso deve ter à disposição estratégias para conservar a igualdade política, princípio basilar para a aplicação do argumento contra o judicial review. Não obstante as instituições democráticas estejam funcionando bem, essa premissa não entra no conteúdo da legislação, logo, cada um fará o seu juízo de valor a respeito das leis criadas (WALDRON, 2010). Assim, para Waldron, a Teoria Política deveria se preocupar com a forma de organização e funcionamento das estruturas e instituições democráticas que compõem um Estado constitucional (WALDRON, 2016).

A partir da primeira pressuposição, pode-se inferir que não há sentido para a existência de um controle judiciário que revise as decisões tomadas democraticamente seja por representantes eleitos, seja diretamente pelos eleitores. Sob a perspectiva somente do bom funcionamento das instituições democráticas, a intervenção do Judiciário no sentido de, em grau extremo, anular situações debatidas em espaços democráticos não se sustentaria (WALDRON, 2010).

O segundo pressuposto é o de que as instituições judiciais da sociedade em questão também estejam, razoavelmente, em funcionamento, isto é, estruturadas e politicamente independentes ${ }^{8}$. Nessa conjuntura, os tribunais devem atuar ao encontro de resolver controvérsias e defender o Estado de direito, outrossim, estão autorizados a realizar o judicial review sobre as ações do poder executivo - decretos autônomos, medidas provisórias e leis delegadas (WALDRON, 2010).

No Brasil, indivíduos tornam-se juízes de duas maneiras, por aprovação em concurso público ou por nomeação, logo, os tribunais são instituições não representativas, já que são compostas por pessoas não eleitas. Nesse diapasão, magistrados não estão vinculados a posicionamentos políticos, ou pelo menos não deveriam estar, uma vez que não representam eleitores. Em alguns Estados, adverte Waldron, os juízes são eleitos, porém, nem mesmo nessas

\footnotetext{
${ }^{8}$ Não está de modo algum evidente que esta pressuposição esteja atendida na realidade brasileira. $\mathrm{O}$ indício mais evidente de comprometimento desse requisito foi a operação Lava Jato que prendeu a pessoa que estava na frente em todas as pesquisas sobre as eleições presidenciais de 2018. O juiz que esteve à frente da operação depois se tornou ministro da justiça do governo daquele que foi o principal beneficiado pela referida prisão.
} 
circunstâncias, os tribunais aparecem como órgãos representativos e passíveis de responsabilidade eleitoral como o são as instituições do poder legislativo (WALDRON, 2010).

Segundo Waldron, os tribunais atuam, na sociedade aqui pensada, em respeito a alguns parâmetros: agem de acordo com as demandas levadas por particulares - cujo objetivo é ter seu direito tutelado pela jurisdição - logo, os tribunais não exercem suas competências por iniciativa própria ou de maneira abstrata; os magistrados, componentes dos órgãos colegiados, ficam adstritos às demandas que lhe são apresentadas - de forma binária e contenciosa; os tribunais remetem a decisões anteriormente tomadas pela mesma instituição com o objetivo de, em caso de haver semelhanças, aplicá-las ao caso em discussão com fulcro de, quando possível, aperfeiçoá-las, uma vez que se necessita adequação à lide em questão. Por fim, presume-se que os juízes sejam pessoas com certo status na sociedade e, também como partes dela, estejam comprometidos com o reconhecimento de direitos individuais e de minorias. Todavia, tal premissa não exclui o fato de os indivíduos que ocupam cargos de juízes poderem discordar com relação ao conteúdo e aos efeitos de tais liberdades (WALDRON, 2010).

A terceira pressuposição, cuja essência liga-se, inclusive, com o exercício da atividade jurisdicional - como já explicitado - trata-se do compromisso assumido por parte da maioria dos cidadãos com direitos individuais e de minorias. Essa parcela acredita que as minorias devam ter reconhecidos direitos com certo grau de apoio. Existe, nesse sentido, um consenso acerca da importância dos direitos humanos. Por outro lado, existem pessoas que não compartilham dessa visão de comprometimento, entretanto, esta é uma posição não prevalecente. A prova de que esse comprometimento existe é que, tal sociedade, bem como muitas outras, adotou uma declaração de direitos, a qual compõe uma constituição, seja ela escrita ou não (WALDRON, 2010).

Esse é outro pressuposto questionável se cotejado com a realidade brasileira. Não se pode dizer que há um consenso acerca da importância dos direitos humanos e sequer é possível dizer de forma categórica que seja uma posição majoritária. Parcelas significativas da sociedade brasileira revelam hostilidade aos direitos humanos, além, sobretudo, de figuras relevantes da política institucional, desde o Presidente da República, ministros, deputados, senadores. Nesse sentido, o Judiciário ainda acaba se tornando um espaço, talvez o último, no qual os direitos fundamentais podem funcionar como trunfos.

Como quarta e última pressuposição, tem-se que, na sociedade discutida, não obstante a presença do compromisso da maior parte da população com os direitos, existem discordâncias a respeito de quais direitos devam ser conservados. Tal questão verte, consequentemente, para 
aspectos políticos. Isso define, em certa medida, o tipo de Estado com o qual se lida - mais voltado à lógica de mercado, liberal, ou com observância dos parâmetros concernentes ao bem-estar social. Waldron exemplifica algumas situações, nas quais há divergência sobre direitos:

(...) aborto, ação afirmativa contra discriminação de minorias, legitimidade da redistribuição ou interferência governamental no mercado, direitos de suspeitos de crimes, significação preciso [sic] de tolerância religiosa, direitos culturais de minorias, regulamentação dos discursos e gastos em campanhas eleitorais, e assim por diante (WALDRON, 2010, p. 114).

Os casos mencionados, nessa perspectiva - apesar de haver o comprometimento com a ideia de direitos individuais e de minorias - continuam a ser pontos controvertidos. Dessa maneira, é possível que os direitos sejam levados a sério pelos indivíduos e, ao mesmo tempo, que esses mesmos indivíduos discordem no que diz respeito a quais direitos devam ser reconhecidos e preservados. No entanto, pressupõe-se que essa discordância, na maioria das vezes, se dê de forma razoável, sob os princípios da boa-fé (WALDRON, 2010). Waldron atesta que muitos autores pertencentes à seara da Teoria Política têm mais interesse em debater acerca das teorias da justiça do que sobre o embate entre os indivíduos a respeito do significado da justiça. É necessário, portanto, atentar-se para quais os meios de resolução das discordâncias entre cidadãos utilizados pelas diversas sociedades (WALDRON, 2014).

Nesse ínterim, a Declaração de Direitos da sociedade em questão torna-se um meio de influência sobre as discordâncias existentes entre os indivíduos comprometidos com a ideia de direitos. Para o autor, as constituições escritas conservam a desvantagem de fomentar as teorias interpretativas entre os juristas e o formalismo textual rígido (CONSANI, 2014). Waldron constata que, em um ambiente passível de haver o judicial review, este ficará limitado a tentar convencer de que as divergências acerca dos direitos são questões de mera interpretação ao invés de confrontálas de maneira eficaz (WALDRON, 2010).

Por outro lado, ele considera que a constituição pode ser um instrumento de fortalecimento da democracia. Porém, para isso, as declarações de direitos devem ser entendidas como espaços que incentivem as deliberações políticas e não como restrições à soberania popular. De acordo com o autor, é preciso questionar "Whether it is actually the point of a constitution to constrain government, as opposed to empower it, is something that needs to be discussed" (WALDRON, 
2012) $)^{9}$. O constitucionalismo liberal, nesse sentido, é criticado por Waldron, na medida em que foca no aspecto restritivo das constituições (CONSANI, 2014).

\subsubsection{A atuação do STF}

A atividade do Poder Judiciário no Brasil, principalmente no que concerne ao STF, reflete os pontos criticados por Waldron. Uma pesquisa realizada por Virgílio Afonso da Silva, com ministros e ex-ministros do Supremo, indica, de maneira prática, a falha na deliberação judicial. Segundo Silva, o STF é um dos tribunais que mais têm votos divergentes publicados, no entanto, quando estes são elaborados antes da deliberação, acabam tornando-se meros votos vencidos, o que representa a maioria dos casos. ${ }^{10}$ Quais as razões para o grande número de votos divergentes e concorrentes no STF? Muitos ministros acreditam que a ausência de deliberação prévia é uma das causas, bem como a prática de levar o voto pronto para a deliberação, fato que prejudica a discussão (SILVA, 2015).

A grande quantidade de trabalho também foi apontada pelos ministros como um fator de aumento das decisões divergentes, na medida em que a falta de tempo empobrece o debate. A publicidade, muito em decorrência da TV Justiça foi ainda levada em consideração. Por último, um ministro apontou a heterogeneidade dos ministros como uma causa para a grande quantidade de divergência nas sessões do STF. Silva demonstra que a tese da heterogeneidade dos juízes não se sustenta, uma vez que desde 1988 há um padrão, que conta com poucas exceções: “(...) os ministros são homens, brancos, cristãos, casados (com pessoas do sexo oposto), classe média-alta, entre 50 e 65 anos de idade quando de sua posse, e, antes de chegar ao STF, foram advogados, promotores ou juízes" (SILVA, 2015, p. 2014).

Importante ressaltar que o fato de os ministros apontarem a ausência de deliberação prévia como uma das causas do número de votos divergentes, isso não quer dizer que estejam defendendo uma discussão anterior. Da mesma forma, os ministros não vêm problema na existência de votos divergentes, ao contrário, consideram enriquecedor, visto que os diferentes argumentos podem ser apresentados. Poucos foram os juízes que afirmaram existir um problema na grande quantidade de

\footnotetext{
${ }^{9}$ Se é realmente o momento de uma constituição para restringir o governo, em vez de fortalecê-lo, é algo que necessita ser discutido (tradução livre).

${ }^{10}$ Silva realiza uma diferenciação entre votos divergentes e votos vencidos. Os primeiros são os votos que divergem do resultado e procuram estabelecer um diálogo com as argumentações que fundamentaram a posição tomada ao criticar os pontos controversos. Já os segundos divergem do resultado, mas não tenta estabelecer o referido diálogo com a posição vencedora.
} 
votos divergentes, os quais denunciariam um modo de deliberar equivocado (SILVA, 2015).

Uma das perguntas feitas aos ministros foi no sentido de questionar se os votos divergentes do STF não seriam na verdade meros votos vencidos, na medida em que já vêm prontos, escritos para a sessão. Os ministros ficaram divididos, alguns destacaram o fato de que os votos vencidos podem se tornar divergentes com as correções feitas após a sessão e antes da publicação. Outra possibilidade seria a reelaboração do voto depois do pedido de vista. Contudo, os próprios ministros que expressaram essas opiniões apontaram as suas limitações. Com relação aos ajustes posteriores, admitem que são poucas as vezes que isso ocorre. E, concernente aos pedidos de vista, defendem que é inviável para um juiz pedir vista em casos nos quais há a pressão da opinião pública (relação homoafetiva por exemplo) (SILVA, 2015).

A minoria reconheceu não haver votos divergentes nas decisões do STF, mas apenas votos vencidos. A última pergunta realizada foi se haveria razões para que um ministro, mesmo entendendo a matéria de forma diversa, não publique o voto divergente. A maioria compreende que sempre se deve externar as discordâncias. Poucos justificaram a não manifestação de divergência a favor da colegialidade ou institucionalidade do tribunal, o que é considerado contraditório por Silva, uma vez que o STF se mostra, cada vez mais, fragmentado e individualista. Dessa forma, a grande maioria dos ministros não vê relação entre o individualismo do STF e a quantidade de votos individuais. Apenas um dos ministros seguiu convicto da discordância com o modelo posto: “É o sistema, é como eu lhe disse, esse sistema não dá margem para pensar se se deve ou não se deve fazer [um voto divergente], ele [o ministro] expôs o ponto de vista dele ou levou pronto, acabou, isso é o que vai constar como tal." (SILVA, 2015, p. 223).

\subsection{A ATIVIDADE DO PODER LEGISLATIVO}

Considerando as particularidades das decisões colegiadas no STF e vistos os pressupostos condicionais de Waldron, faz-se necessário refletir a respeito das disposições formuladas pelo Legislativo. A questão explicitada pelo autor é saber se as resoluções provenientes do parlamento/congresso são terminativas e se devem ou não ser reexaminadas pelo Judiciário.

Embora os membros da sociedade discordem sobre os direitos existentes, deve haver um consenso entre eles sobre o processo decisório legítimo a ser instituído para conciliar as diferenças que surgem. Dessa maneira, a fim de manter a legitimidade do processo de decisão é preciso que haja imparcialidade, voz e participação (WALDRON, 2010).

Ciências Sociais Aplicadas em Revista, v. 20, n. 38, p. 203-237, semestral, janeiro-junho, 2020. 
Contudo, imprescindível é a consciência de que não existe processo decisório perfeito. Assim, seja em um ambiente em que a decisão do legislativo não seja reexaminada ou em conjunturas permeadas pelo judicial review, algumas decisões podem chegar a resultados "errados", na medida em que retiram direitos em vez de conservá-los. Essa situação é inevitável, já que a discordância pressuposta anteriormente permite aferir que "errado" e "certo" são conceitos relativos a depender da pessoa que os utiliza (WALDRON, 2010).

Ao partir da premissa de que não há procedimento perfeito, todos são passíveis de críticas, as quais podem ser divididas em razões "relacionadas ao resultado" e "relacionadas ao processo", cuja análise proporciona a definição de qual método de solução de conflitos é o mais condizente com os pressupostos expostos. As razões relacionadas ao processo independem do resultado que a postura adotada poderá gerar, antes preocupam-se com o meio pelo qual tal decisão será proferida. Já as razões relacionadas ao resultado projetam-se, justamente, no fim almejado. Dessa forma, procura-se o procedimento que vise à realização daquele determinado resultado, cuja valoração (decisão certa, errada, justa ou injusta) torna-se importante (WALDRON, 2010).

De acordo com Waldron, o objetivo de se determinar um procedimento decisório legítimo é a sua capacidade de dirimir as discordâncias concernentes a direitos. À vista disso, é inviável ter como parâmetro de análise as razões relacionadas ao resultado, uma vez que visam decisões controvertidas, haja vista a valoração dos resultados pretendidos. As razões relacionadas ao processo, por sua vez, apresentam parâmetros mais adequados para a análise dos procedimentos. Isso não quer dizer que os resultados não sejam aspectos importantes na tomada de decisão, no entanto, as suas razões não servem para sustentar qualquer processo decisório, nem mesmo aquele favorável ao judicial review (WALDRON, 2010).

Alguns pontos relacionados ao resultado são, comumente, direcionados a favor do judicial review. A saber: o fato de que as questões referentes a direitos sejam levadas aos tribunais por meio de lides particularizadas; a atuação dos juízes ser dirigida a uma Declaração de Direitos e o raciocínio e a fundamentação terem grande importância na aplicação da tutela jurisdicional (WALDRON, 2010).

Com relação ao primeiro ponto, pode-se levantar a crítica de que à medida que um caso é levado aos mais altos graus recursais, as características de seus litigantes, as quais particularizam a demanda apresentada, desaparecem. Destarte, apesar de, inicialmente, os conflitos acerca de direitos aparecerem nos tribunais sob a forma de situações reais, a questão controversa torna-se 
abstrata quando analisada pelos tribunais superiores (WALDRON, 2010). (STF, STJ, TSE, TST e STM $)^{11}$.

Quando se fala em uma atuação dos tribunais orientada a um texto normativo hierarquicamente superior, admite-se a problemática legitimidade do controle realizado pelo judiciário. Os juízes, nesse ambiente de protagonismo do judiciário, remetem suas decisões constantemente às Declarações de Direitos a fim de legitimar as suas convicções e, por vezes, criam as suas próprias "molduras jurídicas", extrapolando os limites constitucionais. Ademais, as deliberações nos tribunais, muitas vezes, tangenciam à questão abordada ao darem exagerada importância a aspectos secundários em suas argumentações, em uma tentativa desesperada, novamente, de as conferir legitimidade (WALDRON, 2010).

Essa mesma análise pode ser utilizada para confrontar o último ponto costumeiramente levantado a favor do judicial review. O fato de os votos dos juízes serem fundamentados nada revela acerca da adequação da revisão judicial. O Legislativo, no exercício de suas funções típicas, também apresenta suas razões de decisão no momento do debate. Todavia a fundamentação realizada pelo Judiciário e aquela feita pelos órgãos do legislativo são qualitativamente diferentes. Enquanto os juízes preocupam-se em se afirmar legítimos para decidir acerca de tal caso, o parlamento/congresso debate sobre o mérito da questão (WALDRON, 2010).

Já as razões relacionadas ao processo, como exposto anteriormente, são mais adequadas à análise do procedimento decisório a ser adotado, uma vez que têm poder tanto de pender contra quanto a favor do judicial review. Entretanto, tem-se que os argumentos a favor do controle exercido pelo judiciário são, substancialmente, mais fracos e não se sustentam facilmente (WALDRON, 2010).

Sob essa lógica, duas questões podem ser apontadas como problemáticas quando se adotam decisões por meio do poder legislativo. Primeiro, "por que uma decisão é adotada por um grupo privilegiado de pessoas? (513 deputados federais e 81 senadores no caso do legislativo federal)" e, segundo, "por que não se deu maior peso a este ou aquele ponto de vista?". As democracias, contudo, apresentam respostas razoáveis a essas indagações. De início, pode-se levantar a teoria das eleições imparciais, cujo conteúdo diz respeito à igualdade com que os eleitores foram tratados para a composição do parlamento/congresso. A segunda questão pode ser respondida ao se invocar

\footnotetext{
${ }^{11}$ Destaca-se que o sistema de constitucionalidade no Brasil é o misto: formado pelos sistemas difuso, concreto e concentrado, abstrato. $\mathrm{O}$ controle de constitucionalidade abstrato não se baseia em casos concretos. Dessa forma, o argumento de que à medida que as ações, baseadas em situações reais, sobem as instâncias judiciais tornam-se abstratas não se sustenta sob essa perspectiva, uma vez que as ações já são originariamente pautadas em demandas abstratas.
} 
o princípio da decisão majoritária (DM). Segundo Waldron, a junção das diferentes formas de como o princípio da DM é utilizado - na composição do parlamento/congresso e nos processos legislativos - refletem uma utilização satisfatória dessa teoria (WALDRON, 2010).

Adiante, essas mesmas indagações podem ser feitas com relação ao judicial review desta maneira: "por que somente onze indivíduos (no caso do STF) podem decidir acerca de temas que influenciam a vida de milhões de pessoas?" e "por que os juízes não dão mais peso a este ou aquele ponto de vista defendido por determinado cidadão?”. As respostas, entretanto, não são tão convincentes se atreladas à revisão judicial (WALDRON, 2010).

A primeira questão poderia ser respondida baseada na legitimidade dos órgãos que nomeiam os juízes, quando se analisam os tribunais superiores. Todavia este constituiria um argumento meramente de autoridade, calcado sobre um parâmetro de legitimidade indireta - vez que não vem, originariamente, do povo, detentor do poder constituinte - e limitada. Concernente à segunda indagação, o princípio da DM é aplicado às deliberações judiciais de forma injustificável. As decisões no poder judiciário são tomadas por maioria de votos, entretanto, os juízes não são representantes dos indivíduos. Logo, não há razão para pressupor que os juízes reivindiquem a DM para fins de igualdade nos processos decisórios, já que participar desses constitui prerrogativa de sua função. Waldron, nesse sentido, assevera, “(...) não há argumento de imparcialidade adicional a favor do uso da DM pelos tribunais, como há para seu uso no legislativo.” (WALDRON, 2010, p. 142). Essa é uma crítica também de Rodriguez (RODRIGUEZ, 2013), na medida em que o autor questiona a ausência de verdadeira deliberação nos juízos colegiados. As razões dos votos não são plenamente debatidas, o que permitiria uma maior atuação dos poderes de argumentação e convencimento. Ao contrário, os votos chegam prontos, sem espaço para mudanças de posição.

Além disso, no caso brasileiro, o procedimento para alteração constitucional demanda maiorias qualificadas para aprovação nas duas casas legislativas. Nos tribunais, por outro lado, a depender da natureza da ação e da decisão, é possível que alterações significativas sejam feitas mediante deliberações por maioria simples, em órgãos com número restrito de juízes.

Diante do analisado, portanto, Waldron compreende que apesar de os juízes serem nomeados por autoridades eleitas (a quem o povo delegou poder), as credenciais democráticas de que gozam os magistrados são comparativamente inferiores àquelas que detém o legislativo. Legisladores têm um vínculo direto com a manifestação de vontade dos cidadãos. ${ }^{12} \mathrm{O}$ Poder

\footnotetext{
12 WALDRON, Jeremy. A essência da oposição ao judicial review. In: BIGONHA, Antonio Carlos Alpino; MOREIRA, Luiz.
} 
legislativo, portanto, é uma instituição criada para o objetivo - função típica - de legislar. A sua estrutura é pensada a fim de proporcionar a maior transparência à população. O Judiciário, ao contrário, apesar de possuir uma função atípica de legislar, não foi organizado e pensado para esse objetivo. Por essa razão, o exercício da legislação pelo Judiciário apresenta-se, por diversas vezes, carente de transparência e legitimidade, o que demonstra problemas estruturais nesse tipo de atuação por parte dos magistrados.

Por último, um argumento levantado pelos defensores do judicial review diz respeito ao preconceito negativo que as minorias tópicas sofrem na sociedade. Dizem, os defensores, que somente o controle exercido pelo judiciário poderia reconhecer e conservar os direitos pertencentes a minorias, especialmente, nos casos em que as minorias decisórias e tópicas se encontram. Há uma presunção generalizada de que o apoio ou simpatia às causas de grupos minoritários esteja mais presente entre os pertencentes a elites políticas do que entre as pessoas comuns. E, ao comparar os simpatizantes de elite que compõem o legislativo e aqueles que compõem o judiciário, o argumento é de que estes últimos estão mais capacitados para garantir tais direitos. Contudo, não há razão para se presumir o apoio aos direitos de minorias esteja concentrado nas elites políticas, isso remonta, justamente, de um histórico receio da autonomia popular ou, nas palavras de Waldron, de "antigos preconceitos sobre o processo decisório democrático" (WALDRON, 2010, 156). O autor considera que o Legislativo dispõe de mais mecanismos de controle e participação popular que o Judiciário.

À vista disso, pode-se considerar que Waldron tem um claro posicionamento no que diz respeito à condução da sociedade. Ele entende que, para conservar o ideal democrático que as constituições declaram, é preciso que a democracia seja reconhecida como um espaço de confrontos. Nessa toada, a participação política, direta ou indiretamente por meio de representantes é essencial para o autogoverno (COSANI, 2014). Diferentemente de outros autores que consideram a democracia representativa como inferior à democracia direta, Waldron faz uma defesa da democracia representativa como desejável nas sociedades modernas.

\section{CONSIDERAÇÕES FINAIS}

Neste artigo buscou-se discutir aspectos da relação entre o Poder Judiciário e a democracia no que concerne, especificamente, às contribuições de Jeremy Waldron para a análise do sistema de controle judicial existente - o qual é permeado pelas disputas de discurso entre póspositivismo/neoconstitucionalismo e positivismo jurídico. 
No primeiro tópico, questionou-se a ideia de Constituições como pré-compromisso, que serviriam para restringir a soberania popular "desenfreada". Nesse sentido, foi apontado o agigantamento do Judiciário, principalmente, quando essa instituição usurpa a tarefa de legislar, o que traduz a preterição dos espaços democráticos, organizados, originalmente, para a função política.

O tópico 2, em um primeiro momento, tratou da posição da democracia em relação ao neoconstitucionalismo característico da globalização econômica. Alguns fenômenos são percebidos nessa situação como a deslegalização e a desconstitucionalização como resultado de um processo no qual a economia suplanta o debate público. Percebe-se, aqui, uma inversão de valores, na medida em que os interesses financeiros tomam desmedida proporção, a ponto de se falar de uma constituição dirigente invertida. A constituição como pré-compromisso tem suas bases corroídas no cenário neoliberal a ponto de ser possível questionar se ainda é possível adotar esse paradigma como efetivamente existente ou como mero pressuposto teórico manejado para fins argumentativos.

Ademais, pôde ser observada uma tendência ao pós-positivismo atrelada à reivindicação de elementos com elevado caráter moral que confere amplos poderes aos juízes e permitem que as suas decisões sejam desvinculadas do texto constitucional. Expôs-se, logo, os parâmetros do neoconstitucionalismo adotado no Brasil, cujo conteúdo conjuga as versões pragmática e moralista desse movimento. Adiante, foi possível traçar os argumentos que questionam a adoção do póspositivismo e mostram a sua fragilidade, uma vez que, primordialmente, ele se sustenta em ataques a um positivismo jurídico que em nada coincide com a realidade.

Ainda no tópico 2, a propensão à judicialização da política foi discutida especialmente no que concerne à utilização de ações diretas de inconstitucionalidade como instrumento político indispensável. Questiona-se se não existem meios mais adequados para a concretização do fazer político, que privilegiem a participação popular.

Por último, no terceiro tópico, deu-se especial atenção às contribuições de Jeremy Waldron referentes ao questionamento do sistema de controle judicial posto atualmente, ao constante repúdio à ideia de democracia como espaço de confrontos e à percepção do conceito sincrônico de povo. A crítica de Waldron quanto à suposta necessidade do sistema de controle judicial foi dividida em duas partes: na compreensão da atividade do judiciário e na compreensão da atividade do legislativo.

Ciências Sociais Aplicadas em Revista, v. 20, n. 38, p. 203-237, semestral, janeiro-junho, 2020. 
Waldron estabelece quatro pressupostos para a sustentação do argumento acerca da desnecessidade do judicial review. A dificuldade encontrada foi de perceber até que ponto esses pressupostos estariam preenchidos na sociedade brasileira.

O primeiro pressuposto é o funcionamento das instituições democráticas de forma razoavelmente bem. Somente a partir dessa pressuposição, a revisão judicial sobre a legislação se tornaria um instrumento de pouca utilidade, na medida em que, se as decisões foram tomadas em um espaço democrático - com participação popular - qual o sentido de o Judiciário elaborar alguma determinação acerca do seu conteúdo?

O segundo pressuposto atenta-se para o funcionamento do próprio Judiciário, o qual deve, também, estar operando de maneira razoável. Nessa toada, Waldron descreve algumas características que teria o Judiciário integrante de uma sociedade sujeita às premissas por ele elaboradas. $\mathrm{O}$ autor imagina tribunais independentes, cujos magistrados não estão vinculados a posicionamentos políticos.

Em um terceiro momento, a pressuposição é de que a maior parte dos indivíduos que compõem a tal sociedade estão, em certa medida, comprometidos com a ideia de proteção aos direitos de minorias. Ou seja, há um consenso na população de que os direitos de grupos politicamente marginalizados devam ser fomentados. No entanto, isso não quer dizer que todas as pessoas concordem em quais direitos devem ser conservados ou não, e essa é a quarta pressuposição, que reconhece a democracia como espaço de confrontos, no qual as pessoas divergem a respeito de determinados assuntos, contudo, possuem meios de intermediação dessas diferenças a fim de chegar a solução mais adequada à sociedade em questão.

Ademais, a partir da perspectiva de Waldron, observou-se a existência de uma discrepância entre a democracia baseada na soberania popular como prevê o Estado Democrático de Direito e a concretização de decisões relevantes na órbita do Judiciário. A democracia em meio ao papel ativo do Judiciário depara-se com a existência de uma elite jurisdicional, a qual não se apresenta como capaz de refletir as diversas identidades que compõem o povo. Torna-se necessário, portanto, pensar estratégias que prestigiem a atuação popular como um conjunto de pluralidades. Em última instância, o que está aqui em questão é a definição do direito e o seu papel na afirmação da democracia.

Nesse sentido, foi possível, ao longo do texto, problematizar a constante do afastamento do povo dos lugares de decisão. Se o povo é o fundamento do Estado Democrático de Direito, nada mais coerente que ele exerça, diretamente e/ou por meio de representantes, a função deliberativa 
acerca dos assuntos que influenciam sobremaneira na forma como estes mesmos indivíduos ocupam os espaços sociais.

Sabe-se que, em momentos de crise, as instituições democráticas são postas a prova e, por vezes, suas funções são questionadas. A Constituição da República de 1988 declara a interdependência e autonomia dos poderes, no entanto, percebe-se uma subversão de funções na atualidade. Refletindo um resgate do populismo, o Poder Judiciário tenta moldar o texto constitucional à "voz das ruas".

A tomada de decisões do Judiciário, principalmente no que diz respeito à atuação do Supremo Tribunal Federal aproxima-se da tendência neoconstitucionalista que, em países como o Brasil, pode representar um gatilho para o enfraquecimento das garantias constitucionais.

Por outro lado, ao encontro da função contramajoritária da corte suprema, o STF avança em questões sociais importantes como o reconhecimento da união homoafetiva. Não obstante à resposta do Judiciário frente o desenvolvimento da sociedade, imprescindível faz-se questionar se tais decisões não poderiam ser elaboradas com a participação do povo. Se a democracia pressupõe um espaço de concomitância de vozes, por que deixar, exclusivamente, a cargo de pessoas não eleitas, a deliberação de questões que envolvem os cidadãos como um todo? É nesse sentido que se defende uma tomada de decisões que privilegie a participação popular, a qual é mais evidente na atividade legislativa. Entende-se, portanto, que o controle judicial se torna desnecessário quando a atuação do Legislativo reflete a democracia enquanto concomitância de vozes.

À vista do que foi discutido, pode-se considerar que a negação do debate político, do confronto de ideias, equivale a refutar a própria democracia que se busca preservar. Tornar-se imprescindível, portanto, discutir quais os melhores modelos para se prestigiar a participação popular a fim de se evitar recair em parâmetros absolutos.

Além disso, os pressupostos para o desenvolvimento da teoria de Waldron não podem ser considerados plenamente atendidos na realidade brasileira. Para além dos problemas estruturais da nossa sociedade, como a profunda desigualdade social que erige o debate sobre a democracia a outro patamar, ainda existem os problemas conjunturais de tendência autoritária, os quais tornam o debate sobre a democracia ainda mais complexo.

Importa recordar que o Judiciário, num contexto de perda de direitos e enfraquecimento das instituições democráticas tem se tornado o último e único lugar de reivindicações. Ademais, a crítica legítima que deve ser feita ao Judiciário tem sido apropriada por setores autoritários para 
revogar esse último espaço para garantia de direitos das minorias. Só é admissível uma crítica ao Judiciário que pretenda aprofundar e não suplantar a democracia.

O sentido de democracia utilizado aqui é o sentido liberal/formal de democracia, que é capaz de admitir que a pluralidade de partidos, eleições periódicas, alternância de poder e funcionamento das instituições seriam condições suficientes para atestar a sua existência, mesmo que a desigualdade social permaneça em patamares extraordinários no cenário mundial, que parcela considerável da população continue sem condições materiais básicas para exercício dos direitos fundamentais e que a política de extermínio da população negra e periférica permaneça em curso.

As críticas de Waldron dependem de pressupostos que, se não inexistentes, estão enfraquecidos em nossa sociedade, de modo que a ampliação de sua atuação é também resultado não só causa - de problemas em nossa democracia. Nesse contexto, os outrora críticos do ativismo judicial se defrontam com a posição contraditória de defesa do Judiciário da forma como ele vem exercendo as suas funções. Isso porque existe uma cínica apropriação das críticas legítimas às instituições - razão pela qual tais posições ganham adesão - como fundamento para defesa de projetos autoritários e neofascistas.

Alguns pontos identificados na pesquisa, como o recurso ao Judiciário em detrimento da mobilização popular, a definição da política como conflito, a concepção sincrônica de povo e os dois sentidos de democracia centrados da institucionalidade - legislativa ou jurisdicional suscitaram o questionamento por outros parâmetros de democracia. Pensar a democracia em termos de instituições que não abandonam completamente o elitismo em países periféricos como o Brasil, um dos mais desiguais do mundo, é limitar o alcance semântico da democracia. Embora as contribuições de Jeremy Waldron sejam importantes para identificação dos limites e contradições da democracia pressuposta no neoconstitucionalismo, ela não deixa de apresentar as suas próprias limitações. Este trabalho, porém, não se propôs a enfrentar as contradições das concepções institucionais/burguesas de democracia, não por ser menos relevante, mas por delimitação teórica.

\section{REFERÊNCIAS}

ALEXY, R. Teoria da argumentação jurídica: a teoria do discurso racional como teoria da fundamentação jurídica. Rio de Janeiro: Forense, 2017.

BARRETO, V.; OLIVEIRA, R. de; STRECK, L. S. Ulisses e o canto das sereias: sobre ativismos judiciais e os perigos da instauração de um terceiro turno da constituinte. Revista de Estudos Constitucionais, Hermenêutica e Teoria do Direito (RECHTD), São Leopoldo: UNISINOS. Jul.-dez. 2009. p. 253. 
BARROSO, L. R. Judicialização, Ativismo Judicial e Legitimidade Democrática. (syn)thesis, Rio de Janeiro, v. 1, n. 5, p.23-32, jun. 2012.

BERCOVICI, Gilberto. Soberania e Constituição: Para Uma Crítica do Constitucionalismo. São Paulo: Quartier Latin. 2008.

CONSANI, C. F. A crítica de Jeremy Waldron ao constitucionalismo contemporâneo. Revista da Faculdade de Direito - UFPR, Curitiba, v. 2, n. 59, p.143-173, ago. 2014.

COSTA, P. "Democracia Política e Estado Constitucional". In: COSTA, Pietro. Soberania, Representação, Democracia: ensaios de história do pensamento jurídico. Curitiba: Juruá, 2010. pp.241-274. p. 93.

DIMOULIS, D. Positivismo jurídico: Introdução a uma teoria do direito e defesa do pragmatismo jurídico-político. São Paulo: Método, 2006.

ELSTER, J. Ulises y las Sirenas: estudios sobre la racionalidad e irracionalidad. Tradución de Juan José Utrilla. México: Fondo de Cultura Económica, 1989.

FARIA, J. E. Democracia e governabilidade: os direitos humanos à luz da globalização econômica. In: FARIA, J. E. (org.). Direito e globalização econômica: implicações e perspectivas. São Paulo: Malheiros Editores, 2010.

FARIA, J. E. O direito na economia globalizada. Malheiros, 2002.

HIRSCHL, R. Towards Juristocracy: The Origins and Consequences of the New Constitucionalism. Harvard: Harvard University Press, 2004.

HOLMES, S. Precommitment and the paradox of democracy. In: J. Elster/ R. Slagstad (Orgs.), Contitutionalism and democracy. Cambridge: Cambridge University Press, 1988b. p. 195-240.

KELSEN, H. A democracia. Tradução de Ivone Castilho Benedetti, Jefferson Luiz Camargo, Marcelo Brandão Cipolla e Vera Barkow. São Paulo: Martins Fontes, 2000.

KELSEN, H. Teoria pura do direito. São Paulo: Wmf Martins Fontes, 2009.

MAUS, I. Judiciário como superego da sociedade: o papel da atividade jurisprudencial na "sociedade órfã". Novos Estudos Cebrap, Brasil, n. 58, p.183-202, nov. 2000, p. 185.

NOVAIS, M. M. de. Os heróis vestem toga: norma, direito e exceção na teoria do direito no Brasil. 304 f. Dissertação de Mestrado. Programa de Pós-graduação em Direito. Universidade Federal de Santa Catarina, Florianópolis, 2016.

POWER, T. Presidencialismo de Coalização e o design institucional no Brasil: o que sabemos até agora? Em: SATHLER, A.; BRAGA, R. J. (eds.). Legislativo Pós-1988: Reflexões e Perspectivas. Brasília: Câmara dos Deputados, 2015.

RODRIGUEZ, J. R. Existe direito no Brasil? a cabrocha e o magistrado. In. Como decidem as cortes?: para uma crítica do direito (brasileiro). Rio de janeiro: Editora FGV, 2013. 
SILVA, V. A. da. De quem divergem os divergentes: os votos vencidos no Supremo Tribunal Federal. Direito, Estado e Sociedade, n. 47, 2015.

SPINOZA, B. de. Tratado Político. Trad. N. de Paula Lima. São Pulo: Ícone, 1994.

VIANNA, L. W.; BURGOS, M. B.; SALlES, P. M. Dezessete anos de judicialização da política. Revista de Sociologia da Usp, São Paulo, v. 2, n. 19, p.39-85, nov. 2007.

VIEIRA, O. V. “Supremocracia”. Revistas Direito GV, São Paulo. Vol .4 n.2. jul/dez 2008, pp. 441-464.

WALDRON, J. A dignidade da legislação. São Paulo: Martins Fontes, 2003.

WALDRON, J. A essência da oposição ao judicial review. In: BIGONHA, Antonio Carlos Alpino; MOREIRA, Luiz. Legitimidade da jurisdição constitucional. Rio de Janeiro: Lumen Juris, 2010. p. 93-157.

WALDRON, J. Constitutionalism: A Skeptical View. NYU School of Law, Public Law Research Paper n. 10-87, 2012.

WALDRON, J. Law and disagreement. New York: Oxford University Press, 1999

WALDRON, J. Political political theory. Cambridge: Harvard University Press, 2016. 